\title{
CO-INFECTION BETWEEN INFLUENZA VIRUS AND FLAGELLATED BACTERIA
}

\section{SUMMARY}

Trypsin is required in the hemagglutinin (HA) cleavage to in vitro influenza viruses activation. This HA cleavage is necessary for virus cell entry by receptor-mediated endocytosis. Bacteria in the respiratory tract are potential sources of proteases that could contribute to the cleavage of influenza virus in vivo. From 47 samples collected from horses, pigs, and from humans, influenza presence was confirmed in 13 and these samples demonstrated co-infection of influenza with flagellated bacteria, Stenotrophomonas maltophilia from the beginning of the experiments. Despite treatment with antibiotics, the bacteria remained resistant in several of the co-infected samples (48.39\%). These bacteria, considered opportunistic invaders from environmental sources, are associated with viral infections in upper respiratory tract of hosts. The protease (elastase), secreted by Stenotrophomonas maltophilia plays a role in the potentiation of influenza virus infection. Proteolytic activity was detected by casein agar test. Positive samples from animals and humans had either a potentiated influenza infectivity or cytopathic effect (CPE) in MDCK and NCI H292 cells, Stenotrophomonas maltophilia were always present. Virus and bacteria were observed ultrastructurally. These in vitro findings show that microbial proteases could contribute to respiratory complications by host protease activity increasing inflammation or destroying endogenous cell protease inhibitors.

KEYWORDS: Stenotrophomonas maltophilia; Influenza virus; Co-infections in vitro.

\section{INTRODUCTION}

Influenza virus is the most important cause of viral pneumonia in adults, nevertheless there is also concern regarding pulmonary infection due to adenovirus ${ }^{21}$.

An interaction between bacteria and influenza A virus during the development of influenza pneumonia has been reported in several studies investigating the role of bacterial proteases on the influenza hemagglutinin cleavage $e^{1,3,16,17,25,28}$.

Cleavage of the influenza A virus hemagglutinin (HA) is required for the virus cell entry mediated by endocytosis receptor ${ }^{8}$. Cleavage of the intact HA0 into HA1 and HA2, allows exposure of the amino terminal fusion peptide of the cleavaged HA in viral pathogenicity and tissue tropism ${ }^{11}$. Previous studies have clearly demonstrated the requirement for trypsin in activation by cleavage of influenza $\mathrm{A}$ viruses in vitro ${ }^{7,9,12}$.

Bacteria present in the respiratory tract are potential sources of proteases that could contribute to cleavage influenza virus in vivo. Susceptibility of HA to cleavage by host intracellular proteases is the major factor distinguishing highly virulent avian influenza viruses from avirulent avian and mammalian viruses. Since HAs of avirulent avian viruses contain the multiple basic amino acid sequence $R-X-K / R-R$, these viruses are susceptible to host intracellular proteases, such as furin and PC6 that can activate this avirulent $\operatorname{strain}^{5,23,27}$.

A protease in allantoic fluid, similar to the mammalian blood clotting factor $\mathrm{X}$, was demonstrated to activate influenza virus grown in embryonated chicken eggs, and to determine the specific tissue tropism ${ }^{4,13}$. The tryptase Clara, a trypsin-like protease produced by the rat bronchiolar Clara cell, is secreted into the rat respiratory tract and is capable of cleavage activation of influenza viruses. Similar proteases, however, have not been demonstrated in other mammalian species. Thus, this matter is not yet conclusively determined ${ }^{6}$.

The most probable potential sources of proteases, in vivo, which may contribute to influenza virus cleavage activation are produced by some strains of Streptomyces griseus, Staphylococcus aureus and Streptococcus pyogenes, isolated from human and animal respiratory tracts. Streptokinase and staphylokinase can facilitate cleavage activation by generation of plasmin from plasminogen ${ }^{13,20,26}$.

It is believed that microbial proteases can potentiate the cleavage activation of influenza virus by mechanisms other than direct cleavage of the HA. Studies with staphylokinase, streptokinase and other bacterial proteases indicate that they potentiate cleavage activation by

This work represents a part of the Master Degree Thesis, from the graduate student Andrea Luppi Fernandes Dias (1)-Laboratório de Virologia. Divisão de Desenvolvimento Científico, Instituto Butantan, S. Paulo, SP, Brazil.

(2)-Laboratório de Imunologia Viral. Divisão de Desenvolvimento Científico, Instituto Butantan, S. Paulo, SP, Brazil.

Correspondence to: Dalva A.P. Mancini, Av. Vital Brasil 1500, 05505-900 São Paulo, SP, Brasil. Fone: 55.11.3726-7222, Ramal 2152. E-mail:dapmancini@butantan.gov.br 

47(5): 275-280, 2005.

activating host proteases such as kallikrein, plasmin or thrombin. This could increase inflammation or destroy endogenous protease inhibitors ${ }^{17}$.

Pseudomonas aerugynosa combined with influenza virus has demonstrated enhanced virus titers and pathogenicity in mice ${ }^{17}$. These microorganisms may be opportunist commensals of the human or animal upper respiratory tracts. In contrast, Stenotrophomonas maltophilia are most likely to be opportunistic invaders from environmental sources ${ }^{2}$.

This study evaluated in vitro the co-infection between Stenotrophomonas maltophilia and influenza virus in samples isolated from animals, such as pigs and horses, as well as humans in close proximity with these animals due to their profession. The clinical manifestations of the classical Flu syndrome were not targeted, thereby also taking into account the occurrence of influenza in subclinical infections ${ }^{14,19}$.

\section{MATERIAL AND METHODS}

1. Subjects: A total of 47 individuals ( 24 swines, 11 equines and 12 humans) were studied. No clinical manifestations of influenza illness were observed in these subjects during collection of the samples. The subjects were housed or worked indoors at locations a, b, c with commercial production facilities. Location $b$ was managed in accordance with the rules of good hygiene practices for animal husbandry, while the other locations did not meet these standards ${ }^{24}$.

2. Samples: Material from both the animals and humans were collected with oral-tracheal swabs. These samples were treated in transport medium Eagle $\mathrm{pH}$ 7.2-7.4, with the addition of $1 \%$ bovine albumin, 2,000 U/mL penicillin $\mathrm{G}, 2.5 \mathrm{mg} / \mathrm{mL}$ streptomycin and $25 \mu \mathrm{L} / \mathrm{mL}$ fungizone. The samples were maintained at $2-8^{\circ} \mathrm{C}$ overnight and then the tests were performed ${ }^{3}$.

\section{Virus isolation and characterization}

a. Chicken embryonated eggs: $0.2 \mathrm{~mL}$ of the sample were inoculated into allantoic cavities of 10-day-old chick embryos, using three eggs from Leghorn "specific pathogen free" (spf) chicken for each sample. The inoculated eggs were incubated at $33{ }^{\circ} \mathrm{C}$ for seven days and then infected fluid was harvested and assayed by HA test, with rooster red blood cells suspension at $0.5 \%$. Samples were considered negative when they did not present the hemagglutinin after three passages in eggs ${ }^{9}$.

b. Cell culture: $0.2 \mathrm{~mL}$ of the sample were used to inoculate two types of tissue cultures: MDCK(canine)(ATCC-CCL34) and NCI H292(human)(ATCC-CC1848) with added trypsin $(0.2 \mu \mathrm{g} / \mathrm{mL}$ ). Both of the cell cultures were incubated at $33{ }^{\circ} \mathrm{C}$ for seven days. The inoculated samples were observed for three passages and, if no cytopathic effect was detected seven days after the inoculation and hemagglutinin in both cellular systems, these samples were considered negative for the presence of the virus?

c. Hemagglutination test: Hemagglutination titers were determined at room temperature in a microtiter system. Serial twofold dilutions of virus $(25 \mu \mathrm{L})$ in phosphate buffered $\mathrm{pH} 7.2$ were mixed with $25 \mu \mathrm{L}$ of a $0.5 \%$ suspension from rooster red blood cells. Hemagglutination titers were determined after one $\mathrm{h}$, unless otherwise started, and are expressed as the reciprocal of the maximum dilution of virus that caused complete agglutination ${ }^{10}$.

d. Influenza A/B Rapid Test (by ROCHE Kit Insert): The test principle is based on the Roche diagnostics: GLORIA (gold-labeledoptically-read-immunoassay). The viral nucleoprotein and viral nucleic acid that are released by lysing the influenza virus envelope with Lysis/ Elution Solution are detected. The test uses two pairs of monoclonal antibodies to specific influenza A and other specific influenza B. Both antibody pairs are conjugated to either biotin and digoxigenin. In the presence of the viral antigen, a sandwich complex is formed, consisting of the biotin-conjugated antibody, the nucleoprotein, and the digoxigenin- conjugated antibody. When the test strip is placed in the reaction cup, the complex migrates chromatographically, solubilizing colloidal gold particles incorporated in the red pad of the strip. The colloidal gold particles bind to the digoxigenin of the complex, which is then bound by the biotin to the immobilized streptavidin on the strip (positive result line). Any excess gold particles continue to migrate to the second line (control line), which then becomes visible. This indicates the correct chromatographic migration. According to the information in the Influenza A/B Rapid Test Kit, no cross reactivity occurs with other probable respiratory viruses or other organisms, such as bacteria or fungi.

4. Bacterial isolates: Samples collected from the subjects presenting bacterial contamination, during viral replication, were submitted to bacterial isolation after three material passages into the medium Tryptic Soy Broth (TSB) at $25-33{ }^{\circ} \mathrm{C}$ for $48 \mathrm{~h}$. Then, samples were collected for bacteria characterization ${ }^{3}$. The Clinical Laboratory of Pharmaceutical Science Faculty of São Paulo University, SP, Brazil, performed the bacteria characterization.

5. Proteolytic activity of the bacterial culture fluid: Stored bacterial isolates were cultured in Tryptic Soy Broth (TSB) and these cultures were centrifuged at $12,000 \mathrm{~g}$ for $15 \mathrm{~min}$ at $4{ }^{\circ} \mathrm{C}$ and filtered through a Millipore $0.45 \mu \mathrm{m}$ pore-diameter syringe filter. This clarified supernatant was tested for proteolytic activity on casein agar plates. The casein agar plates consisting of $25 \mathrm{mM}$ Tris (pH 7.2), $150 \mathrm{mM}$ $\mathrm{NaCl}, 0.6 \%$ casein (Sigma technical grade) and $1 \%$ Bacto Agar (Difco). Aliquots $(10 \mu \mathrm{L})$ of culture supernatants were placed in $3 \mathrm{~mm}$ diameter wells cut in the casein agar and incubated at $37^{\circ} \mathrm{C}$ for $18 \mathrm{~h}$. The plates were overlaid with $3 \%$ acetic acid, and proteolytic activity was noted as a zone of clearing around the sample well. Trypsin $(1 \mu \mathrm{g} / \mathrm{mL})$ was used as a positive control standard ${ }^{3}$.

Caseinolytic activity, relative to trypsin, was determined by measuring the diameter of the proteolytic zones around each well.

6. Electron microscopy: Negative Staining - This is a direct application method for electron microscopy. A digital pipette was used to place a drop $(10 \mu \mathrm{L})$ of viral suspension on the collodion-carboncoated surface of a copper grid. Excess fluid was removed with filter paper, and a drop $(10 \mu \mathrm{L})$ of negative stain (PTA) was added. Excess fluid was removed with filter paper. Then, the grid was air dried overnight, examined on the electron microscope Zeiss 109, operated at $80 \mathrm{kV}$, and the microorganism particles were photographed ${ }^{10}$. 


\section{RESULTS}

The data presented (Tables 1, 2 and 3) for all the tests or single test demonstrate the presence of the influenza virus in samples isolated from pigs, humans and horses and co-infection with Stenotrophomonas maltophilia. The samples isolated from pigs and humans from locations a and c (Tables 1 and 2) were confirmed influenza positive by the Influenza $\mathrm{AB}$ Rapid Test, after screening by $\mathrm{CPE}$ and $\mathrm{HA}$ tests. The sample isolated from pig No. 01 was positive in the first passage in cells and became negative after the third passage, but still egg positive. Of the pig samples tested with casein agar, four grown in eggs and five grown in cell cultures were positive for bacterial co-infection with influenza. Using the same test, the human samples demonstrated five positives, one harvested from egg and four from cell culture systems (Fig. 2). These samples presenting bacterial co-infection, induced intense CPE into the $72 \mathrm{~h}$ in cell cultures such as MDCK and NCI. Data obtained from pig and human samples, from Location $b$, were influenza positives, presented cytopathic effect in MDCK cells, and had not co-infected with bacteria. Regarding the samples collected from horses, belonging to Location c (Table 3), grown in eggs as well as in cell cultures (MDCK and NCI) demonstrated CPE and HA positives. These samples were identified and characterized as Influenza

Table 1

Swine influenza identification/characterization and co-infection with flagellated bacteria

\begin{tabular}{|c|c|c|c|c|c|c|c|c|}
\hline \multirow{3}{*}{$\begin{array}{l}\text { Samples } \\
\text { Location }\end{array}$} & \multirow{4}{*}{$\begin{array}{c}\text { Egg } \\
\text { HA }\end{array}$} & \multicolumn{4}{|c|}{ Cell culture } & \multirow{4}{*}{$\begin{array}{l}\text { Identification/ } \\
\text { Characterization } \\
\text { RT A/B } \\
\text { NT }\end{array}$} & \multirow{2}{*}{\multicolumn{2}{|c|}{$\begin{array}{c}\text { Casein agar bacterial } \\
\text { protease test }\end{array}$}} \\
\hline & & \multicolumn{2}{|c|}{ MDCK } & \multicolumn{2}{|c|}{$\mathrm{NCI}$} & & & \\
\hline & & $\mathrm{CPE}$ & HA & $\mathrm{CPE}$ & $\mathrm{HA}$ & & Egg & Cell \\
\hline $\mathrm{a}$ & & $\mathrm{P}$ & $\mathrm{N}$ & $\mathrm{N}$ & $\mathrm{N}$ & & NT & NT \\
\hline $\mathrm{a}$ & $\mathrm{P}$ & $\mathrm{P}$ & $\mathrm{P}$ & $\mathrm{P}$ & $\mathrm{P}$ & $\mathrm{P}$ & $\mathrm{P}$ & $\mathrm{P}$ \\
\hline $\mathrm{a}$ & $\mathrm{P}$ & $\mathrm{N}$ & $\mathrm{N}$ & $\mathrm{P}$ & $\mathrm{P}$ & $\mathrm{P}$ & $\mathrm{N}$ & $\mathrm{P}$ \\
\hline $\mathrm{a}$ & $\mathrm{P}$ & $\mathrm{N}$ & $\mathrm{P}$ & $\mathrm{P}$ & $\mathrm{N}$ & $\mathrm{P}$ & $\mathrm{P}$ & $\mathrm{P}$ \\
\hline $\mathrm{a}$ & $\mathrm{P}$ & $\mathrm{N}$ & $\mathrm{P}$ & $\mathrm{P}$ & $\mathrm{P}$ & $\mathrm{P}$ & $\mathrm{P}$ & $\mathrm{P}$ \\
\hline $\mathrm{a}$ & $\mathrm{N}$ & $\mathrm{P}$ & $\mathrm{P}$ & $\mathrm{N}$ & $\mathrm{P}$ & $\mathrm{P}$ & $\mathrm{P}$ & $\mathrm{P}$ \\
\hline $\mathrm{a}$ & $\mathrm{N}$ & $\mathrm{N}$ & $\mathrm{P}$ & $\mathrm{P}$ & $\mathrm{P}$ & $\mathrm{N}$ & $\mathrm{N}$ & NT \\
\hline
\end{tabular}

$\mathrm{P}=$ positive; $\mathrm{N}=$ negative; $\mathrm{NT}=$ Not Tested; $\mathrm{CPE}=$ cytopathic effect; $\mathrm{HA}=$ hemagglutination test; $\mathrm{RT}=$ Influenza A/B Rapid Test (ROCHE Lab.).

Table 2

Human influenza identification/characterization and co-infection with flagellated bacteria

\begin{tabular}{|c|c|c|c|c|c|c|c|c|c|}
\hline \multirow{3}{*}{\multicolumn{2}{|c|}{$\begin{array}{l}\text { Samples } \\
\text { Location }\end{array}$}} & \multirow{4}{*}{$\begin{array}{c}\text { Egg } \\
\text { HA } \\
P\end{array}$} & \multicolumn{4}{|c|}{ Cell culture } & \multirow{4}{*}{$\begin{array}{l}\text { Identification/ } \\
\text { Characterization } \\
\text { RT A/B } \\
\text { P }\end{array}$} & \multirow{2}{*}{\multicolumn{2}{|c|}{$\begin{array}{c}\text { Casein agar bacterial } \\
\text { protease test }\end{array}$}} \\
\hline & & & \multicolumn{2}{|c|}{ MDCK } & \multicolumn{2}{|c|}{$\mathrm{NCI}$} & & & \\
\hline & & & $\mathrm{CPE}$ & $\mathrm{HA}$ & $\mathrm{CPE}$ & HA & & Egg & Cell \\
\hline 1 & $\mathrm{a}$ & & $\mathrm{P}$ & $\mathrm{P}$ & $\mathrm{P}$ & $\mathrm{P}$ & & $\mathrm{N}$ & $\mathrm{P}$ \\
\hline 2 & $\mathrm{a}$ & $\mathrm{N}$ & $\mathrm{N}$ & $\mathrm{N}$ & $\mathrm{N}$ & $\mathrm{N}$ & NT & $\mathrm{P}$ & $\mathrm{N}$ \\
\hline 3 & $\mathrm{a}$ & $\mathrm{P}$ & $\mathrm{P}$ & $\mathrm{N}$ & $\mathrm{P}$ & $\mathrm{P}$ & $\mathrm{P}$ & NT & $\mathrm{P}$ \\
\hline 4 & $\mathrm{a}$ & $\mathrm{P}$ & $\mathrm{P}$ & $\mathrm{P}$ & $\mathrm{P}$ & $\mathrm{P}$ & $\mathrm{P}$ & $\mathrm{N}$ & $\mathrm{P}$ \\
\hline 5 & $\mathrm{c}$ & $\mathrm{P}$ & $\mathrm{P}$ & $\mathrm{P}$ & $\mathrm{P}$ & $\mathrm{N}$ & $\mathrm{P}$ & $\mathrm{N}$ & $\mathrm{P}$ \\
\hline
\end{tabular}

$\mathrm{P}=$ positive $; \mathrm{N}=$ negative NT = Not Tested CPE = cytopathic effect; HA = hemagglutination test RT = Influenza A/B Rapid Test (ROCHE Lab.).

Table 3

Equine influenza identification/characterization and co-infection with flagellated bacteria

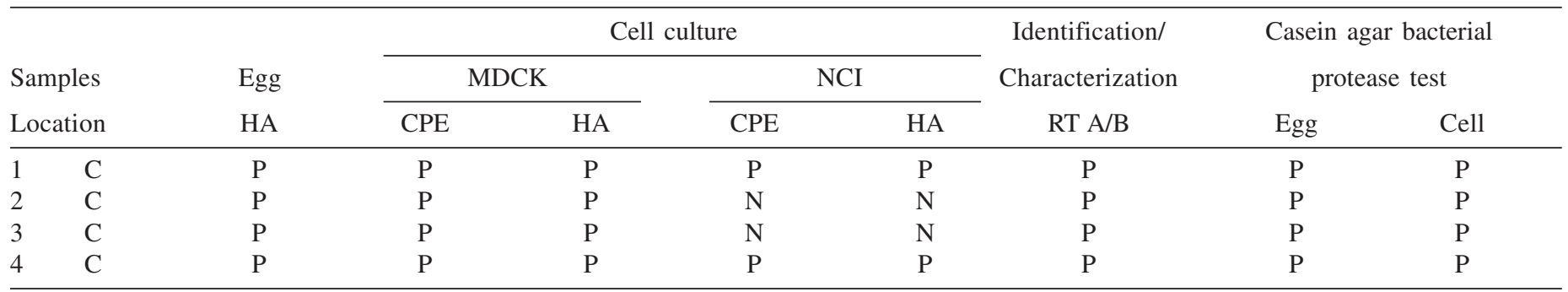

$\mathrm{P}=$ positive; $\mathrm{N}=$ negative; $\mathrm{NT}=$ Not Tested; $\mathrm{CPE}=$ cytopathic effect; HA = hemagglutination test; RT = Influenza A/B Rapid Test (ROCHE Lab.). 

47(5): 275-280, 2005.

by Influenza A/B Rapid Test (Fig. 2), and also revealed co-infection between influenza and the bacteria, Stenotrophomonas maltophilia.

Figure 1 shows the presence of influenza viruses and the flagellated bacteria in the total samples collected. The Influenza A/B Rapid Test results that confirmed the presence of influenza virus in samples from pigs (No. 02, 03, 04, 05, 06) (Table 1) humans (No. 01, 03, 04, 05) (Table 2) and equines (No. 01, 02, 03, 04) (Table 3) are clearly demonstrated in Fig. 2. Figure 3 is an electron micrograph showing the presence of both bacteria and influenza virus in infected samples.

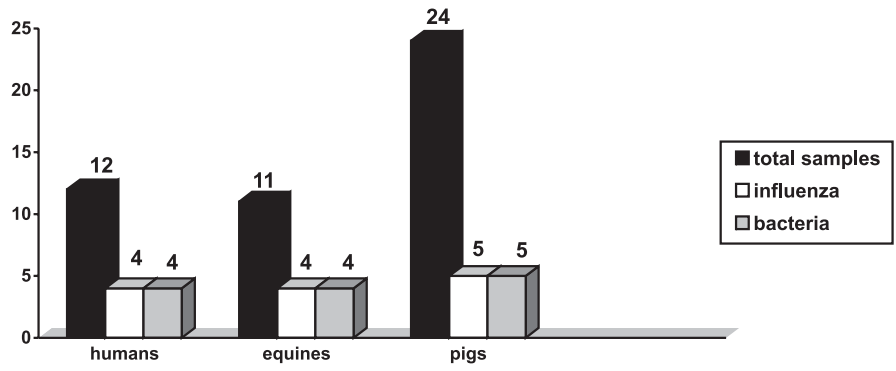

Fig. 1 - Presence of the influenza viruses and Stenotrophomonas maltophilia in isolated samples.

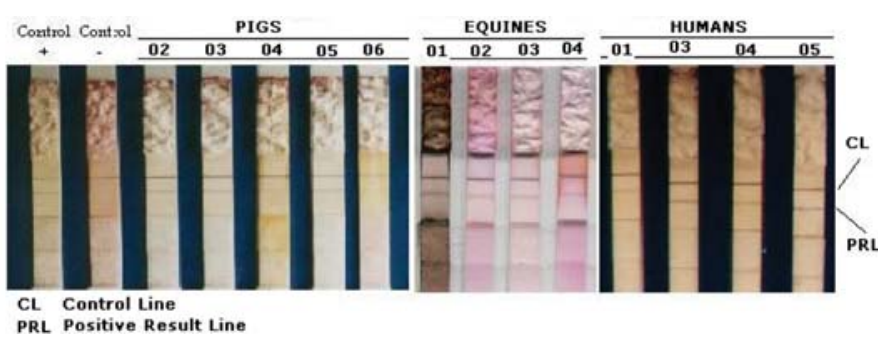

Fig. 2 - Influenza Rapid Test - GLORIA (Gold-Labeled-Optically-Read-Immunoassay).

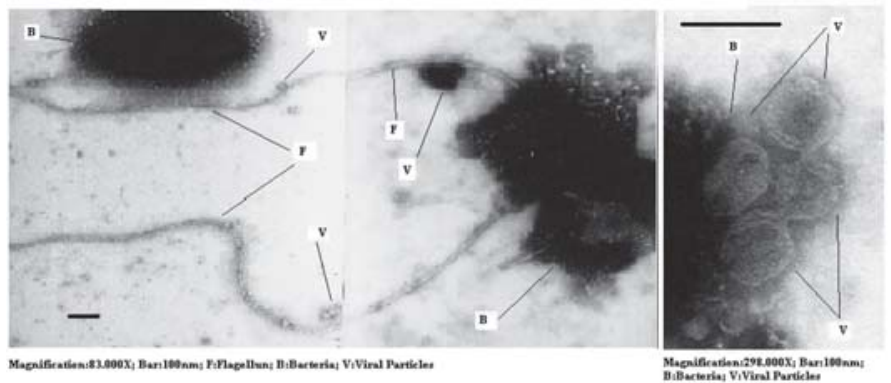

Fig. 3 - Electron micrograph of the flagellated bacteria and influenza virus present in isolate sample.

Thus, microbiological tests demonstrated the presence of Stenotrophomonas maltophilia, in human and animal samples, resistant to the antibiotics streptomycin, penicillin and fungizone, but sensitive to sulfadiazine. The casein agar test showed presence of the Stenotrophomonas maltophilia protease, in those isolate samples, by the halos of proteolytic activity that could be compared with halos of the trypsin used as control (Fig. 4).
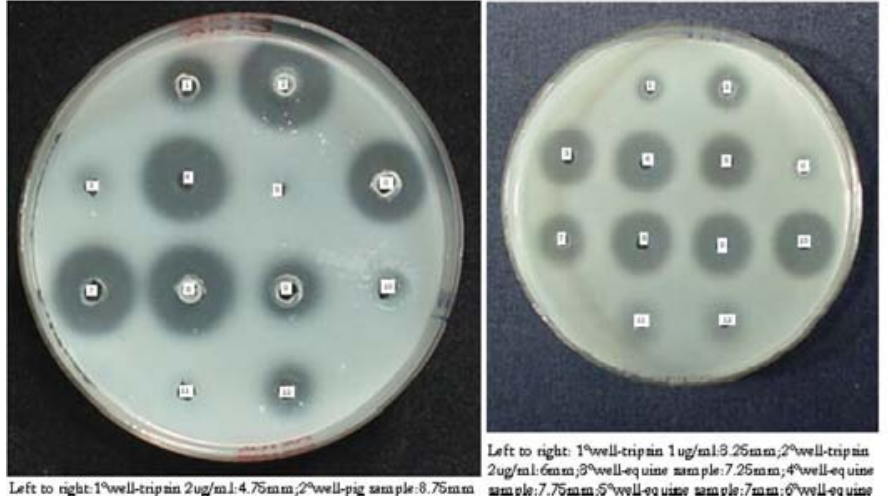

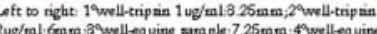

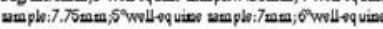

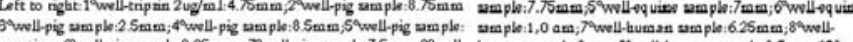

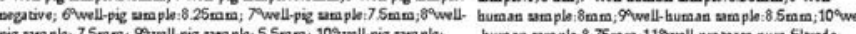

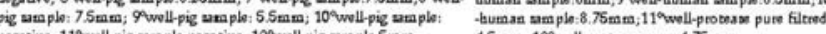

Fig. 4 - Casein Agar Test - Human, Equine and Pig Influenza samples co-infected with Stenotrophomonas maltophilia.

After treatment of the samples with sulfadiazine, the Stenotrophomonas were inactivated and, in consequence of the protease decrease, the intense CPE of the influenza virus was decreased in these cultures, as well as the HA viral titers.

\section{DISCUSSION}

According to the results obtained in this work, with subjects from three different localities of São Roque, SP, Brazil, during the influenza season it was seen that $21.11 \%$ of the thirteen confirmed influenza virus in samples isolated from animals, pigs, horses and from humans (working as veterinarians or feeding the animals) from locations a and $\mathrm{c}$ had been co-infected with Stenotrophomonas maltophilia. While in location $b$ the confirmed influenza samples exhibited no co-infection with bacteria at the time of these experiments. No influenza (negatives) was detected in the remaining 34/47 samples collected. Such coinfection caused exacerbation of the influenza virus, in consequence of the bacterial protease, elastase, by the cleavage and activation of $\mathrm{HA}$ of these viruses which could be detected by the intense cytopathic effect of the infected cell cultures.

Together with previously published data, this in vitro finding suggests that co-infection can complicate the respiratory disease syndrome during influenza virus infection in $v i v o^{18}$. Swine influenza has been previously reported to be complicated by additional bacterial pathogens ${ }^{18,22}$.

In this study, 5/5 pig influenza samples were co-infected with bacteria. The equine samples were submitted to virus isolation, and 4/ 11 were positive for influenza and $100 \%$ of these positive samples were contaminated with the bacteria Stenotrophomonas maltophilia.

In the samples collected from twelve humans (animal feeders and veterinarians) positivity to influenza virus was confirmed $41.63 \%$ (one of which confirmed by the EM) and a similar exacerbation of the infectivity in both cell cultures or in eggs was observed when bacterial co-infection with Stenotrophomonas maltophilia was present. 
Comparing the beginning of the CPE of the virus in monolayers of the MDCK and NCI cells, it was observed that CPE started in the $72 \mathrm{~h}$ when these samples persisted with bacterial contamination, while the others took a longer time of six to seven days for starting the CPE. The Electron Microscopy technique also corroborated the confirmation of positivity obtained by the tests used in this work.

The serological test confirmed in some samples from subjects screened for influenza identification and characterization, is demonstrated in Figure 2.

From these results demonstrating influenza and bacteria coinfection, it may be concluded that the evaluated subjects (humans and animals) were submitted to double transmissions occurring in the two locations studied (a and c) situated in the São Roque region, SP, Brazil. It should be taken into consideration that Stenotrophomonas maltophilia is an opportunistic invader from environmental sources, such as soil or water, and it is probable that this co-infection occurred first among the animals and was then transmitted to the humans. In addition, no subject showed clinical manifestations of the classical Flu syndrome during the sample collection, as has also been reported in other studies ${ }^{14,19}$.

Whether these asymptomatic subjects had clinical manifestations after the oral swab collection times, this would be associated with the level of the transmitted viral charge. It is important to underscore that even a minimal viral charge can possibly increase its potential when in appropriate conditions, as shown by the viral replication methods used here.

It is considered that the more hygienic conditions of the production facilities at location $b$ were responsible for the prevention of virus and bacteria co-infection.

In this study, Stenotrophomonas maltophilia protease developed the same role as trypsin, usually added to influenza virus inoculation in cell culture. Such use aims to increase influenza infectivity, by cleavage of HA of this virus, during its cultivation, as has been demonstrated by the present authors in other work ${ }^{9}$.

In summary, it was concluded that co-infection can occur between bacteria and influenza virus, thereby causing a potential risk to susceptible hosts. Co-infection resulting in respiratory tropism of the influenza virus, such as by Stenotrophomonas maltophilia protease, represents a strong mutual help, facilitating either opportunist bacterial invasion into the respiratory tract or exacerbation of the viral infection through the cleavage activation of the HA influenza. This study may contribute to future knowledge in this field. Further experiments, however, should be performed to analyze direct inter-species transmission of the influenza virus, in the form of zoonoses.

\section{RESUMO}

\section{Co-infecção entre vírus influenza e bactéria flagelada}

Tripsina é necessária na ativação da clivagem do vírus influenza A in vitro. Esta clivagem é importante para entrada do vírus na célula por endocitose mediada pelo receptor celular. Bactérias presentes no trato respiratório são fontes de proteases que podem contribuir na replicação do vírus influenza in vivo. Entre 47 amostras coletadas de cavalos, suínos e humanos, a influenza foi isolada e confirmada em 13 que estavam co-infectadas com bactéria flagelada: Stenotrophomonas maltophilia desde o início destes experimentos. Apesar do tratamento das amostras com antibióticos, as bactérias resistiram em diversas delas (48.39\%). A protease (elastase), secretada pela Stenotrophomonas maltophilia, desenvolveu papel decisivo na potencialização da infecção pelo vírus influenza. Essa atividade proteolítica foi detectada pelo teste de ágarcaseína. Amostras positivas para o vírus influenza isolado em animais, bem como em humanos tiveram potencialização da infectividade (ECP) em células MDCK e NCI-H292, sempre que a Stenotrophomonas maltophilia esteve presente. Os referidos microorganismos, bactéria e vírus foram observados ultra-estruturalmente. Esses achados in vitro demonstram como complicações respiratórias podem ocorrer in vivo, através da contribuição de protease microbiana, provocando aumento da inflamação ou destruição dos inibidores celulares de proteases endógenas, nos hospedeiros susceptíveis à influenza.

\section{ACKNOWLEDGMENTS}

The authors extend their thanks to: Dra. Aurora Marques Cianciarullo and biologist Tânia M. Hosoda, both from the Laboratório de Genética and to Mrs. Luzia da Purificação, da Divisão de Desenvolvimento Científico - Instituto Butantan, for technical assistance in the microorganism micrographs; Roche Laboratories, for donating the Influenza A/B Rapid Test; and FAPESP - Fundação de Amparo à Pesquisa do Estado de São Paulo for financial support Process: 00/03996-0.

\section{REFERENCES}

1. ADERAYE, G. - The etiology of community acquired pneumonia in adults in Addis Ababa. W. Afr. J. Med.,13: 142-145, 1994.

2. BYRUM, B.R. \& SLEMONS, R.D. - Detection of proteolytic bacteria in the upper respiratory tract flora of poultry. Avian Dis., 39: 622-626, 1995.

3. CALLAN, R.J.; HARTMANN, F.A.; WEST, S.E.H. \& HINSHAW, V.S. - Cleavage of influenza A virus $\mathrm{H} 1$ hemagglutinin by swine respiratory bacterial proteases. J. Virol., 71: 7579-7585, 1997.

4. GOTOH, B.; OGASAWARA, T.; TOYODA, T. et al. - An endoprotease homologous to the blood clotting factor $\mathrm{X}$ as a determinant of viral tropism in chick embryo. EMBO J., 9: 4189-4195, 1990 .

5. HORIMOTO, T.; NAKAYAMA, K.; SMEEKENS, S.P. \& KAWAOKA, Y. - Pro-proteinprocessing endoproteases PC6 and furin both activate hemagglutinin of virulent avian influenza viruses. J. Virol., 68: 6074-6078, 1994.

6. KIDO, H.; YOKOGOSHI, Y.; SAKAI, K. et al. - Isolation and characterization of a novel trypsin-like protease found in rat bronchiolar epithelial Clara cells. J. Biol. Chem., 267: 13573-13579, 1992.

7. KLENK, H.D.; ROTT, R.; ORLICH, M. \& BLONDORN, J. - Activation of influenza A viruses by trypsin treatment. Virology, 68: 426-439, 1975.

8. LAZAROWITZ, S.G. \& CHOPPIN, P.W. - Enhancement of the infectivity of influenza A and B viruses by proteolytic cleavage of the hemagglutinin polypeptide. Virology, 68: $440-454,1975$.

9. MANCINI, D.A.P. \& YANO, A.B. - Avaliação da tripsina na multiplicação de vírus influenza em culturas de células MDCK. Rev. Farm. Bioquím. Univ. S. Paulo, 29: 89-95, 1993. 

47(5): 275-280, 2005.

10. MANCINI, D.A.P.; MENDONÇA, R.M.Z.; CIANCIARULLO, A.M. et al. - Influenza nos animais heterotérmicos. Rev. Soc. bras. Med. trop., 37: 204-209, 2004.

11. NAGAI, Y. - Protease- dependent virus tropism and pathogenicity. Trends Microbiol., 1: $81-87,1993$.

12. NAGATAKE, T. - Potentiation of infectivity and pathogenesis of influenza virus host and bacterial proteases. Nippon Rinsho., 61: 1892-1896, 2003.

13. OKAMOTO, S.; KAWABATA, S.; NAKAGAWA, I. et al. - Influenza A virus-infected host boost an invasive type of Streptococcus pyogenes infection in mice. J. Virol., 77: 4104-4112, 2003

14. OLSEN, C.W.; CAREY, S.; HINSHAW, L. \& KARASIN, A.I. - Virologic and serologic surveillance for human, swine and avian influenza virus infections among pigs in the north-central United States. Arch. Virol., 145: 1399-1419, 2000.

15. ROTT, R.; REINACHER, M. ORLICH, M. \& KLENK, H.-D. - Cleavability of hemagglutinin determines spread of avian influenza viruses in the chorioallantoic membrane of chicken embryo. Arch. Virol., 65: 123-133, 1980.

16. RUIZ, M.; EWIG, S.; MARCOS, M.A. et al. - Etiology of community- acquired pneumonia: impact of age, morbidity, and severity. Amer. J. respir. Crit. Care. Med., 160: 397-405, 1999.

17. SCHEIBLAUER, H.; REINACHER, M.; TASHIRO, M. \& ROTT, R. - Interaction between bacteria and influenza A virus in the development of influenza pneumonia. J. infect. Dis., 166: 783-791, 1992.

18. SHOPE, R.E. - Swine influenza. Filtration experiments and etiology. J. Exp. Med., 54: 373-385, 1931.

19. STAMBOULIAN, D.; BONVEHI, P.E.; NACINOVICH, F.M. \& COX, N. - Influenza. Infect. Dis. Clin. N. Amer., 14:141-166, 2000.
20. TASHIRO, M.; CIBOROWSKI, P.; KLENK, H.D. et al. - Role of Staphylococcus protease in the development of influenza pneumonia. Nature, 325: 536-537, 1987.

21. TECSON, F. \& LOURIA, D.B. - Infectious pneumonias: a review. J. Fam. Pract., 41: 201-209, 1977.

22. TIMONEY, J.F.; GILLESPIE, J.H.; SCOTT, F.W. \& BARLOUGH, J.E. - Hagan \& Bruner's microbiology and infectious diseases of domestic animals. Ithaca, Cornell Univiversity, 1988.

23. VEY, M.; ORLICH, M.; ADLER, S. et al. - Hemagglutinin activation of pathogenic avian influenza viruses of serotype $\mathrm{H} 7$ requires the protease recognition motif R-XK/R-R. Virology, 188: 408-413, 1992.

24. VIANA, A.T. - Os suinos: criação prática e econômica. São Paulo, Nobel, 1988.

25. VISHNIAKOVA, L. \& PUTOV, N.V. - The etiology of acute pneumonia. Ter. Arkh., 62: $15-22,1990$

26. WADOWSKY, R.M.; MIETZNER, S.M.; SKONER, D.P.; DOYLE, W.J. \& FIREMAN, P. - Effect of experimental influenza A virus infection on isolation of Streptococcus pneumoniae and other aerobic bacteria from the oropharynges of allergic and nonallergic adult subjects. Infect. Immun., 63: 1153-1157, 1995.

27. WALKER, J.A.; MOLLOY, S.S.; THOMAS, G. et al. - Sequence specificity of furin, a proprotein-processing endoprotease, for the hemagglutinin of a virulent avian influenza virus. J. Virol., 68: 1213-1218, 1994.

28. WATANABE, A.; SHOJI, S.; NUKIWA, T. et al. - Study on respiratory infections in primary care clinic (V). The pattern of distribution on bacteria, Mycoplasma pneumoniae and virus isolated from patients with respiratory infections, who were seen in six private clinics, and clinical efficacy of ciprofloxacin and roxithromycin. Kansenshogaku zasshi., 68: 1359-1366, 1994.

Received: 28 September 2004

Accepted: 13 July 2005 